\title{
Nominalizations and Temporal Prepositions ${ }^{1}$
}

\author{
Veronika Ehrich / Irene Rapp \\ Universität Tübingen \\ veronika.ehrich@uni-tuebingen.de,irene@diderot.de
}

\begin{abstract}
In this paper, we deal with the semantic interaction between $u n g$-nominalizations of different event types and temporal prepositions like während 'during', vor 'before', nach 'after', bis 'until' and seit 'since'. According to the two-level-approach to semantics (Bierwisch 1983, Bierwisch / Lang 1989), we will argue that the meaning of temporal prepositions is determined on the level of semantic form (SF). When combined with an event nominal, the period in time required by the preposition has to be inferred on the level of conceptual structure (CS). Very often, the exact nature of the period in time is determined by pragmatic factors. There are, however, some important restrictions to this inference procedure which rely on the event noun's Aktionsart. In Ehrich/Rapp (2000), it was claimed that eventive ungnominals inherit the Aktionsart of their base verb. This assumption receives strong support by the data presented in this paper.
\end{abstract}

\section{Introduction}

Event nominalizations, as being derived from verbs, share the event structure of their base and thus denote activities, accomplishments, achievements or states. They may function as arguments of temporal prepositions, accordingly (1).

(1) a. Während seiner Krankheit During his illness

b. Bei der Erreichung des Gipfels When reaching the summit

(2) a. Vor der Vernehmung des Zeugen

\section{Before the examination of the witness}

lernte Jonathan Schach spielen. Jonathan learned to play chess.

jubelten die Bergsteiger.

the mountaineers shouted with joy.

studierte der Richter die Akten.

the judge studied the files.

b. Nach der Zerstörung der Stadt

zogen die Eroberer weiter.

After the destruction of the city the conquerors marched on.

(3) a. Bis zur Behandlung durch einen Arzt Until being treated by the doctor

muss der Patient noch warten. the patient has still to wait.

b. Seit der Absperrung des Geländes Since the barring off of the site

parken hier keine Autos mehr. there are no more cars parking here.

Temporal prepositions require calendaric or eventive complements. This requirement is so strong that they even coerce an event reading onto non-eventive base nouns.

\footnotetext{
${ }^{1}$ The research reported here was supported by a grant from DFG (Eh $\left./ 80 / /-3\right)$. We thank the participants of the workshop on nominalization (Tübingen, April 2001) for their comments and the discussion, Carmen Wunderle for her work on that subject, Kim Dunklau and Yvonne Teußer for their technical help. Comments offered by Ewald Lang and Ilse Zimmermann lead to some revisions of an earlier draft. All remaining errors are our own responsibility.
} 
(4) a. Während der Dias bin ich eingeschlafen / Während die Dias gezeigt wurden... During the slides I fell asleep / While the slides were presented...

b. Bei einem Glas Wein kamen sie sich näher / Als sie ein Glas Wein tranken... Over a glass of wine they got closer / When having a glass of wine

c. Vor seinem Buch war Hans weithin unbekannt / Bevor das Buch veröffentlicht wurde....

Before his book John was widely unknown /Before the book got published...

d. Nach der Autobahn begann es zu schneien / Nachdem wir die Autobahn verlassen hatten...

After the highway it began to snow / After we had left the highway...

e. Vor dem Doktor kommt erst der Magister / Bevor man den Doktorgrad erwerben kann...

Before the doctor's degree comes the master's degree / Before one can obtain a doctor's degree...

f. Seit dieser Pizza ist mir schlecht / Seit ich diese Pizza gegessen habe....

Since this pizza I feel sick / Since I have eaten this pizza...

In virtue of being nouns, nominalizations are necessarily untensed and thus do not specify relational time information. Whether the event referred to by a nominal is anterior/posterior to the speaking time or overlapping with it has to be inferred from encyclopedic knowledge (5a) or from temporal modifiers combining with the noun in question $(5 b)$.

(5) a. die Ermordung Cäsars

the murder of Cesar

b. die gestrige Aufführung der Oper

yesterday's performance of the opera

The matrix verb and its tense are another source for the temporal interpretation of a nominal. Tense as used in (6) tells us that the flight to the North Pole is in the future (6a) or in the past (6b).

(6) a. Der Flug zum Nordpol wird Spaß machen.

The flight to the North Pole will be fun.

b. Der Flug zum Nordpol machte Amundsen berühmt.

The flight to the North Pole was the source of Amundsen's fame.

A given tense, however, does not always provide an unequivocal temporal interpretation for a nominal in its scope.

(7) a. Vor der Messung der Schadstoffbelastung wurde das Messgerät repariert.

Before the measuring of the pollution, the gauge was repaired.

b. Vor der Messung der Schadstoffbelastung konnte das Grundstück nicht verkauft werden. 
Before the measuring of the pollution, the site could not be sold.

(7a) relates the repair of the gauge to the time at which the measurement is carried out. (7b) relates the selling of the site to a time after the measurement has been completed. The temporal information conveyed by (7a) corresponds to the information provided by a simple past $(8 \mathfrak{a})$; the temporal information conveyed by $(7 b)$ corresponds to a past perfect ( $8 b)$.

a. Bevor die Schadstoffbelastung gemessen wurde,...

Before the pollution was measured, ...

b. Bevor die Schadstoffbelastung gemessen worden war,...

Before the pollution had been measured, ...

This kind of ambiguity is typical for nominals denoting accomplishments. It does not arise in cases where the nominal refers to an activity or a state ${ }^{2}$.

(9) a. Vor der Belagerung der Stadt entkamen die Einwohner aufs Land.

Before the siege of the city, the inhabitants escaped to the countryside.

b. Vor seiner Krankheit trieb Jonathan viel Sport

Before his illness, Jonathan did a lot of sports.

The inhabitants' escape precedes the onset of the siege in (9a), the time, when Jonathan was doing a lot of sports is anterior to the outburst of his illness in $(9 \mathrm{~b})$; there is no pluperfect paraphrase possible (10).

(10) a. Bevor die Stadt belagert wurde,... / *Bevor die Stadt belagert worden war Before the city got besieged,... / Before the city had got besieged, ...

b. Bevor er krank war, ... /*Bevor er krank gewesen war

Before he was ill,... / Before he had been ill,...

The interaction between ung-nominalizations of different event types and temporal prepositions is the main issue of this paper. In particular, we examine the interrelations between the selectional restrictions of the preposition and the Aktionsart of its event complement. In Ehrich/Rapp (2000), it was claimed that ung-nominalizations preserve the Aktionsart of their base verb. This assumption is supported by the data presented in this paper: We will show that the distinction between activities, achievements, accomplishments and states plays an important role for the combination of ung-nominalizations with temporal prepositions. Während 'during', for instance, requires protracted events, achievement nominals are not allowed. In other cases the selectional requirements of the preposition induce an inference: if a 'punctual' preposition like vor 'before' or nach 'after' takes a protracted event as its complement we have to infer the delimiting point in time required by the preposition. Often, the exact nature of the delimiting point can only be determined by pragmatic factors - however, there are some important restrictions to pragmatic reasoning which rely on the event noun's Aktionsart. The selectional requirements imposed by the prepositions can only be explained if we assume that an ung-derivation does not alter the Aktionsart of the base verb.

\footnotetext{
${ }^{2}$ In this paper, we restrict ourselves to states situated in space and time. States of this kind are denoted by stage level predicates. We won't take into account non-situative states denoted by individual level predicates / statezero-predicates in the sense of Klein (1994). (Cf. also Ehrich 1992, Rapp 1996, Maienborn 2001)
} 
We will proceed as follows. In section 2 we consider temporal prepositions like in 'in', um 'at', and während 'during', which lexicalize an inclusion relation between an event and a time span. In 3 we investigate the prepositions which express that an event is anterior (vor 'before', bis 'until') or posterior (nach 'after', seit 'since') to a point in time.

\section{Temporal Inclusion between THEME and RELATUM}

According to the two-level-approach to semantics (Bierwisch 1983, Bierwisch / Lang 1989), the meaning of a linguistic expression (in our case, the meaning of a temporal preposition) is determined on the level of semantic form (SF), whereas its reference is resolved on the level of conceptual structure (CS). SF-information specifies the contextually invariant meaning of a given lexical item, including its decomposition into sublexical atomic predicates and its argument structure. On the level of SF, a lexical entry (LE) of a given language is assigned an abstract semantic structure underlying each occurrence of LE - independent of the context in which it is used. CS provides a rich base of knowledge which specifies linguistic as well as extra-linguistic information, including pragmatic (Gricean) principles of utterance interpretation, information about the specific context in which LE is used as well as encyclopaedic information about natural laws or cultural stereotypes.

Prepositions express a relation between a THEME and a RELATUM. Spatial prepositions like in relate the place of a THEME object to the PLACE of a RELATUM object (cf. Bierwisch 1988, Herweg 1989, Klein 1990):

(1) a. The wallet is in the bag.

THEME: $\mathrm{x}$ RELATUM:y

b. in

$$
\lambda y \lambda x[\operatorname{PLACE}(\mathrm{x}) \subseteq \operatorname{PLACE}(\mathrm{y})]
$$

Temporal prepositions express a relation between the event time of a THEME situation e and a RELATUM time T. The abstract semantic form of a temporal preposition is given in (2).

$$
\begin{aligned}
& \text { PREP } P_{\text {temp }} \\
& \lambda T \lambda \mathrm{e}[\mathrm{Temp} \text { (e) } \boldsymbol{R} \mathrm{T}]
\end{aligned}
$$

Temporal in locates the time of the THEME event within a given RELATUM time T, where $T$ is a calendaric-time-denotation (3).

(3) a. Im nächsten Jahr/im nächsten Monat/in dieser Woche wird Jonathan zwanzig. Next year/next month/this week, Jonathan will turn twenty.

b. $\quad$ in Temp $_{\text {Temp }}$

$$
\lambda \mathrm{T} \lambda \mathrm{e}[\mathrm{Temp}(\mathrm{e}) \subseteq \mathrm{T}]
$$

The meanings of um ('at') and während ('during') are similar to that of temporal in, except that $u m$ requires a point in time and während requires a protracted period of time as RELATUM.

(4) a. Jonathan rief um drei Uhr mittags an. Jonathan called at 3 p.m.

b. Jonathan rief während der Ferien an. Jonathan called during the holidays. 
(4') a. um

$\lambda \mathrm{T} \lambda \mathrm{e}[\mathrm{Temp}(\mathrm{e})=\mathrm{T}]$ where $\mathrm{T}$ is a calendaric point in time

b. während

$\lambda \mathrm{T} \lambda \mathrm{e}[\mathrm{TEMP}(\mathrm{e}) \subseteq \mathrm{T}]$ where $\mathrm{T}$ is a protracted period in time

One could argue that in the case of während the relation between THEME and RELATUM does not have to be proper inclusion. The following examples seem to indicate just an „overlap" relation:

(5) a. Während der Ferien arbeitete sie in der Fabrik, (und danach auch noch).

During the holidays she worked in the factory, and did so still afterwards

b. Während der Ferien war sie krank, (und zuvor auch schon).

During the holidays she was ill, and she had already been ill before

However, if we have a closer look at the examples we notice that an „overlap“ relation is only possible if the THEME event is an activity or a state. Accomplishment and achievement THEMEs have to be included in the RELATUM:

(6) a. Während der Ferien las sie ein Buch.

During the holidays she read a book.

b. Während der Ferien brach sie sich ihr Bein.

During the holidays she broke her leg.

It is a well-known fact that homogeneous events (activities and states) are distributive in nature. An activity/state which is included in a certain time interval may be part of a bigger event of the same type overlapping with this specific interval. Hence, we may generalize that während always expresses an inclusion between THEME and RELATUM: Activities and states - as they are homogeneous - may however be subparts of larger events going beyond this interval.

Let us turn to the specific nature of the RELATUM and especially to the question, whether an event noun can appear as RELATUM. Interestingly, in and um only occur with calendaric time specifications, event nominals are excluded. Während and bei, on the other hand, allow for an event noun as RELATUM (7).

(7) a. Während der Hochzeit betrank sich der Brautvater.

During the wedding celebration, the bride's father got drunk.

b. Bei der Hochzeit betrank sich der Brautvater.

At the wedding celebration, the bride's father got drunk.

(7a) asserts that the bride's father got drunk at some time during the wedding party. Worid knowledge suggests that the father of the bride usually takes part in the wedding party. Thus, both (7a) and ( $7 b$ ) can be truthfully asserted about a situation where the bride's father got drunk while attending the wedding party. This, however, does not follow from the meaning of während ('during') repeated in (8); (7a) may be true, even when the bride's father did not take part in the wedding party and got drunk at a different occasion covering a subintervall of the wedding party time. 
(8)

während ('during')

$\lambda \mathrm{T} \lambda \mathrm{e}[\mathrm{Temp}(\mathrm{e}) \subseteq \mathrm{T}]$, where $\mathrm{T}$ is the event time of a protracted event

(7b), on the other hand, does entail that the bride's father took part in the wedding party. The difference between während and bei is evident in (9), where (9a) says that Jonathan earned a lot of money at a time when he was a student of German, whereas (9b) tells us that studying German was the source of Jonathan's earning money.

(9) a. Während seines Germanistik-Studiums hat Jonathan viel Geld verdient.

While studying German, Jonathan earned a lot of money.

b. Bei seinem Germanistik-Studium hat Jonathan viel Geld verdient.

By studying German, Jonathan earned a lot of money.

Spatial bei ('at') locates the place of the THEME object in the proximal neighbourhood of the place of the RELATUM. (10a) tells us that the car is parked near the church, (10b) says that the chair occupies a place close to the place of the desk.

(10) a. Das Auto parkt bei der Kirche.

The car is parked near the church.

b. Der Stuhl steht beim Schreibtisch.

The chair is located close to the desk.

Bei as opposed to an indicates that THEME and RELATUM are close neighbours in terms of their respective locations, but are not related to each other in any specific way beyond spatial proximity. (10b) is, for instance, inappropriate with respect to a situation where the chair is placed in the working space of the desk (see Lang 1993) for more detail).

(11) bei LOC $_{10}$

$\lambda y \lambda x[\operatorname{PLACE}(\mathrm{x}) \subseteq(\operatorname{PROX}(\mathrm{y})-\operatorname{PLACE}(\mathrm{y}))]^{3}$

Eventive bei is different in that the THEME event is part of the RELATUM event. Actually, eventive bei denotes a mereological (part-whole) relation between THEME and RELATUM ${ }^{4}$.

(12) bei Event ('at')

$\lambda \mathrm{e}^{\prime} \lambda \mathrm{e}\left[\mathrm{e}^{\prime} \subseteq \mathrm{e}\right]$ where $\mathrm{e}$ is an eventuality of any type

This semantic representation is supported by the fact that bei - in contrast to während-never takes a purely temporal expression as its RELATUM (*bei den Ferien 'at the holidays', *bei der nächsten Woche 'at the next week'): eventive bei does not express a relation between times, but between events. The temporal relation expressed by bei in $(7,9)$ is indirect $(13)$.

$$
\forall \mathrm{e}^{\prime} \forall \mathrm{e} \exists \mathrm{t}^{\prime} \exists \mathrm{t}\left[\mathrm{e}^{\prime} \subseteq \mathrm{e} \& \mathrm{t}^{\prime}=\operatorname{Temp}\left(\mathrm{e}^{\prime}\right) \& \mathrm{t}=\operatorname{Temp}(\mathrm{e}) \rightarrow \mathrm{t}^{\prime} \subseteq \mathrm{t}\right]
$$

\footnotetext{
${ }^{3} B e i$ locates the THEME in the proximal neighbourhood of the RELATUM, but excludes from PROX (y) the space covered by the RELATUM itself.

${ }^{4}$ A similar usage of spatial bei is to be found in examples like Fritz ist beim Bäcker ('Fritz is at the bakery'), where the place of the THEME is included in the place or RELATUM.
} 
Both während and bei impose specific restrictions on the RELATUM event. Während requiring a protracted event as complement can be combined with nominalizations of state, activity or accomplishment verbs, but is deviant with nominalizations of achievement verbs:

(14) a. State

Während seiner Krankheit blieb Jonathan zu Hause.

During his illness, Jonathan stayed at home.

b. Activity

Während der Befragung des Zeugen trank der Polizist Kaffee.

During the questioning of the witness, the policeman drank a cup of coffee.

c. Accomplishment

Während der Zubereitung des Essens trank sie ein Glas Sherry.

During the preparation of the meal, she had a glass of sherry.

d. Achievement

*Während der Erreichung des Gipfels jubelten die Bergsteiger.

During the reaching of the summit, the mountaineers shouted with joy.

The same restriction holds for the conjunctional counterpart of während. However, the temporal conjunction während allows a re-interpretation as an adversative conjunction when combined with an achievement verb (15). A re-interpretation of this kind is impossible for prepositional während in combination with an event nominal.

(15) a. Während Arved den Südpol erreichte, blieb Reinhold im Camp zurück.

While Arved reached the South Pole, Reinhold remained behind in the camp.

b. Während Jonathan eine Anstellung fand, blieb Ferdinand arbeitslos.

While Jonathan found himself a job, Ferdinand was still unemployed.

$B e i$, in contrast to während, can combine with nominalizations of achievement verbs (16a). Due to its mereological meaning, bei requires the THEME to be part of the RELATUM. This is why (16b) is ungrammatical. Staying at home is a state accompanying an illness, but it is not part of the illness. ${ }^{5}$

(16) a. Bei der Erreichung des Gipfels jubelten die Bergsteiger.

When reaching the summit, the mountaineers shouted with joy.

b. *Bei seiner Krankheit blieb Jonathan zu Hause.

When he was ill Jonathan stayed at home.

Während expressing a relation between times can be used where THEME and RELATUM are just temporally coincident (17a). Bei expressing a mereological relation between events requires that THEME and RELATUM overlap in time as well as with respect to at least one of the protagonists involved (17b).

(17) a. Während der Sprengung seines Hauses saß der Eigentümer ahnungslos in der Oper.

\footnotetext{
${ }^{5}$ There is also an emphatic use of bei in sentences like Bei deiner Krankheit solltest du im Bett bleiben ('Seen the fact that you are so ill, you should stay in bed') (personal comment by Ewald Lang).
} 
During the blowing-up of his house, the owner was sitting unsuspecting in the opera house.

b. *Bei der Sprengung seines Hauses saß der Eigentümer ahnungslos in der Oper. At the blowing-up of his house, the owner was sitting unsuspecting in the opera house.

To summarize: In, um, während and bei all lexicalize an inclusion relation between THEME and RELATUM. In and um only occur with proper time phrases. Während is also a genuine temporal preposition expressing mere inclusion of the thematic time into the RELATUM time; it can however take a protracted event or state nominal as its RELATUM. Bei expresses a mereological relation between events. As a consequence, the temporal interpretation conveyed by bei is only indirect, mediated by the fact that an event e' which is part of an event e covers a subsection of the event time covered by e.

\section{$3 \quad$ Anteriority and Posteriority}

In this section, we treat the prepositions vor 'before', nach 'after', bis zu 'until' and seit 'since', which locate the THEME at some time anterior or posterior to the RELATUM. This RELATUM is either given by the denotatum of a calendaric TADV or by the time of an event:

(1) a. Jonathan reiste vor Montag / vor der Tagung ab.

Jobn left before Monday / before the conference.

b. Ich traf J. nach $5 \mathrm{Uhr} /$ nach der Tagung.

I met J. after 5 o'clock / after the conference.

c. Jonathan las bis $5 \mathrm{Uhr} / \mathrm{bis}$ zu der Aufführung.

Jonathan. was reading until 5 o'clock / until the performance.

d. Jonathan wartete seit Mitternacht / seit der Explosion.

Jonathan was waiting since midnight / since the explosion.

Our claims are the following: We assume that vor/nach/bis/seit temporally locate the THEME event by reference to a point in time, which we call the delimiting point. The relation between this delimiting point and the THEME event is lexically specified for each preposition and will be formalized below (3.1). The delimiting point is introduced by the RELATUM. Things are easy if the RELATUM is given by a punctual TADV like fünf Uhr 'five o'clock' however, if the RELATUM is a time span or a protracted event, the relevant point in time has to be inferred from contextual knowledge. We will show in 3.2 that the relevant inference procedure crucially depends on the Aktionsart for event nominals, and that it does not always yield unambiguous results. Hence, we claim that it is only the relation between the THEME and the delimiting point that is lexically specified for each preposition. The delimiting point itself has to be deduced by event structure based inference rules.

\subsection{The lexical meaning of the prepositions: The relation between the THEME event and the delimiting point}

To account for the specific meaning of each preposition we have to introduce some notions of interval semantics. Any event e spans over a given time interval T. T is a closed interval, iff it is initially as well as terminally closed. 
(2) Initial Closure: Init ( $T$ ) is the initial closure of $T$, iff

a. $\quad$ Init $(\mathrm{T}) \subseteq \mathrm{T}$ and

b. $\forall \mathrm{t}[\mathrm{t} \subseteq \mathrm{T} \& \mathrm{t} \neq \operatorname{Init}(\mathrm{T}) \rightarrow \mathrm{t}>\operatorname{Init}(\mathrm{T})]$

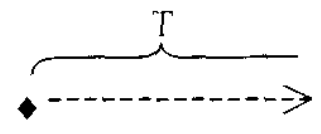

Init $(\mathrm{T})$

(3) Terminal Closure: Term ( $\mathrm{T}$ ) is the terminal closure of $\mathrm{T}$, iff

a. $\quad$ Term $(\mathrm{T}) \subseteq \mathrm{T}$ and

b. $\quad \forall \mathrm{t}[\mathrm{t} \subseteq \mathrm{T} \& \mathrm{t} \neq \operatorname{Term}(\mathrm{T}) \rightarrow \mathrm{t}<\operatorname{Term}(\mathrm{T})]$

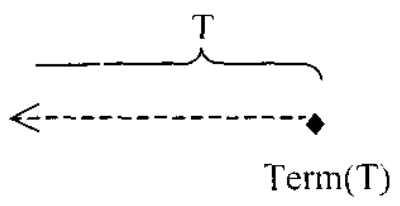

An interval is semi-closed, iff it has either an initial or a terminal closure, but not both. An interval is open, iff it is neither initially nor terminally closed. If $T$ is a point in time, it coincides with both its initial and its terminal closure.

For any closed interval $T$, there is a PRE-TIME $T^{\prime}$ of $T$ and a POST-TIME $T$ ' ' of $T$, such that $T$ ' and $T^{\prime}$ ' are separated from $T$ by a delimiting point $t^{*}$.

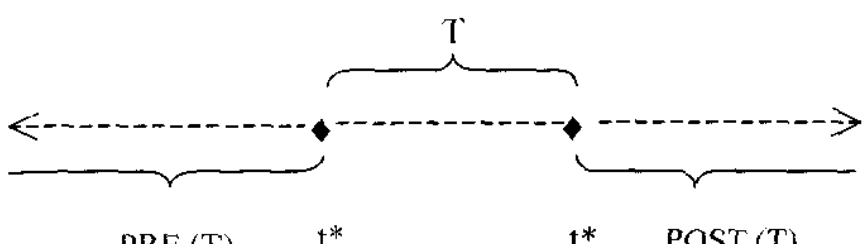

$\operatorname{PRE}(\mathrm{T}) \quad \mathrm{t}^{*} \quad \mathrm{t}^{*} \quad \operatorname{POST}(\mathrm{T})$

(5) DELIMITING POINT: $t^{*}$ is the delimiting point between two subsequent intervals $T$, and $T$, iff $t^{*} \subseteq$ Term $\left(T^{\prime}\right) \cap \operatorname{Init}(T)$ and $\neg \exists t\left[t \neq t^{*} \& t \subseteq T e r m\left(T^{\prime}\right) \cap\right.$ Init $\left.(T)\right]$

(6) PRE-TIME: T' is the Pre-Time of T (T'= PRE (T)), iff

i. $\exists t^{*}\left[t^{*} \subseteq\right.$ Term $\left.\left(T^{\prime}\right) \cap \operatorname{Init}(T)\right]$ and

ii. $\quad \forall \mathrm{t}^{\prime}\left(\mathrm{t}^{\prime} \subseteq \mathrm{T}^{\prime} \& \mathrm{t}^{\prime} \neq \mathrm{t}^{*} \rightarrow \mathrm{t}^{\prime}<\mathrm{t}^{*}\right] \quad$ and

$\forall \mathrm{t}\left[\mathrm{t} \subseteq \mathrm{T} \& \mathrm{t} \neq \mathrm{t}^{*} \rightarrow \mathrm{t}>\mathrm{t}^{*}\right]$

(7) POST-TIME: T' is the Post-Time of T (T" $=$ POST (T)), iff

i. $\quad \exists t^{*}\left[t^{*} \subseteq \operatorname{Term}(T) \cap \operatorname{Init}\left(T^{\prime \prime}\right)\right] \quad$ and

ii. $\forall \mathrm{t}^{\prime \prime}\left[\mathrm{t} " \subseteq \mathrm{T}^{\prime \prime} \& \mathrm{t}\right.$ ' $\left.\neq \mathrm{t}^{*} \rightarrow \mathrm{t}^{\prime \prime}>\mathrm{t}^{*}\right]$ and

iii. $\forall \mathrm{t}\left[\mathrm{t} \subseteq \mathrm{T} \& \mathrm{t} \neq \mathrm{t}^{*} \rightarrow \mathrm{t}<\mathrm{t}^{*}\right]$

These definitions guarantee that semi-closed intervals possess a clearly defined PRE-/POSTTIME by picking out the first / last point in time as the delimiting point.

Temporal vor locates the event under discussion within the PRE-TIME of the RELATUM-Time T. Nach locates Temp (e) within the POST-TIME of the RELATUM-Time T.

(8) vor ('before'): $\quad \lambda T^{\lambda}$ e $[$ Temp (e) $\subseteq$ PRE (T)] 
nach ('after'): $\quad \lambda_{\mathrm{T}} \lambda_{\mathrm{e}}[\mathrm{Temp}(\mathrm{e}) \subseteq \operatorname{POST}(\mathrm{T})]$

We tend to understand vor / nach as locating the THEME in proximal distance to the onset or termination of the RELATUM, which implies that J. arrived no later than 10 o'clock in (9a) and shortly before the beginning of the conference in $(9 \mathrm{~b})$ :

(9) a. Jonathan kam nach 9 Uhr an.

John arrived after 9 o'clock.

b. Jonathan kam vor der Tagung an.

John arrived before the conference.

This understanding, however, is not part of the semantic meaning of nach / vor, but recurs to pragmatic reasoning. (9a) induces a scalar implicature in terms of the first maxim of quantity ('Say as much as necessary'): if a speaker uttering (9a) had wished to convey the message that Jonathan arrived after 10 o'clock he could have said so. Hence, the SF-representation of vor / nach just tells us that the THEME is located before or after a delimiting point $\mathrm{T}$ - it does not tell us anything about the distance to this point.

Telic THEME events have to be closed within PRE (T) or POST (T) respectively. In the case of achievements, the event time Temp (e) coincides with its initial as well as with its terminal closure.

(10) a. Jonathan kam vor der Konferenz/vor sieben an.

Jonathan arrived before the conference / before seven.

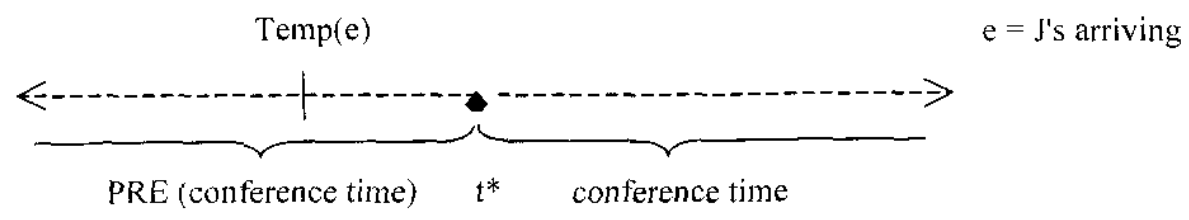

b. Jonathan kam nach der Konferenz / nach sieben an.

Jonathan arrived after the conference / after seven.

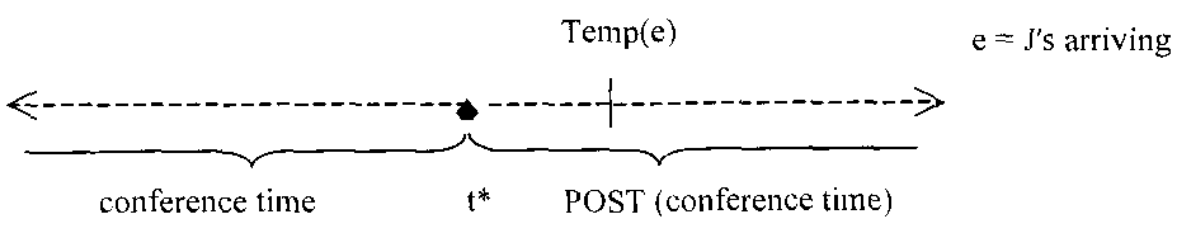

Accomplishments denote a protracted event that is initially and terminally closed in the PREor POST-TIME of the RELATUM:

(11) a. Er löste das Problem vor dem Abendessen / vor sieben.

He solved the problem before dinner / before seven.

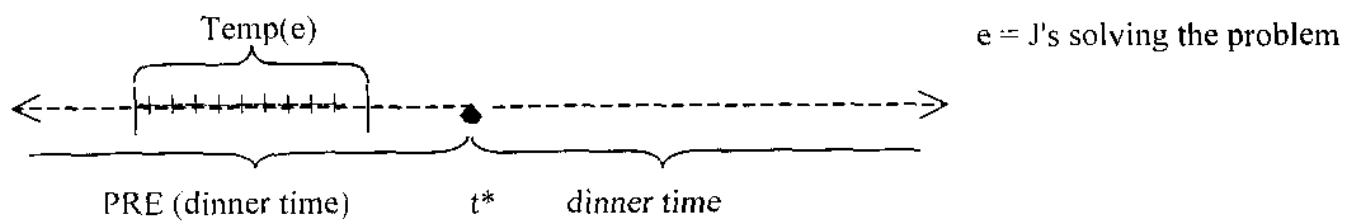


b. Er löste das Problem nach dem Abendessen / nach sieben.

He solved the problem after dinner / after seven.

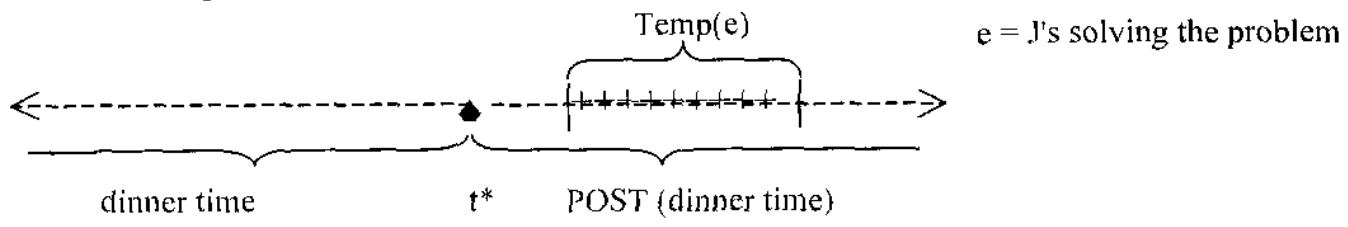

One might argue that in the case of (11b), the accomplishment could have its onset before the delimiting point: If someone solves a problem after seven, he could have started to think about it before seven. However, we assume that this thinking process is not part of the solving procedure, but belongs to a preparatory stage. If we take an accomplishment with incremental THEME (12), we easily notice that the whole event starts after the delimiting point:

(12) a. Er aß den Apfel nach dem Abendessen.

He ate the apple after dinner.

b. Sie malte das Bild nach 8 Uhr. $^{6}$

She painted the picture after 8 o'clock.

If the event under consideration is an activity $(13 a, c)$ or a state $(13 b, d)$, its event time may span a period extending beyond the delimiting point $t^{*}$.

(13) a. Vor sieben Uhr morgens / vor dem Frühstück spielte Jonathan Flöte.

Before seven a.m. / before breakfast Jonathan played the flute

b. Vor sieben Uhr morgens / vor dem Frühstück saß Jonathan am Schreibtisch .

Before seven a.m./ before breakfast Jonathan was sitting at his desk.

c. Inge sprach mit Walter nach Mitternacht / dem Frïhstück.

Inge talked to Walter after midnight / after breakfast.

d. Inge war nach Mitternacht / dem Frühstück müde.

Inge was tired after midnight / after breakfast.

(13a) can be truthfully asserted about a situation where Jonathan began playing his flute before seven and finished doing so after seven. (13d) is true, if Inge was tired after breakfast, no matter whether she had been tired even before that:

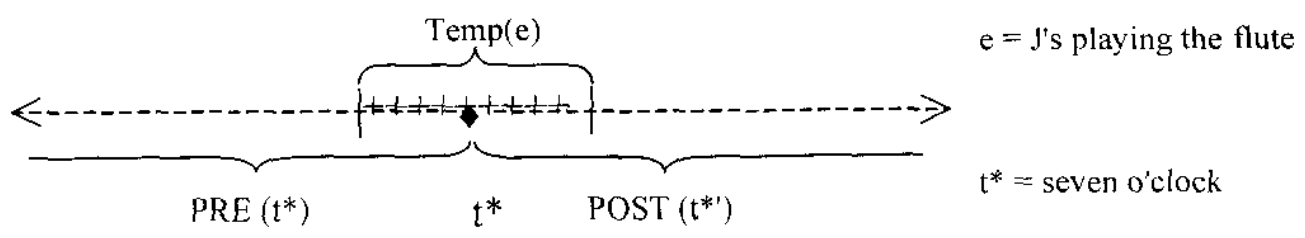

\footnotetext{
"It is interesting to notice the difference to aufessen, fertigmalen/vollenden, achieve":

(i) Sie aß den Apfel nach dem Abendessen auf.

She finished the apple after dinner.

(ii) Sie vollendete das Bild nach 8 Uhr.

She accomplished the picture after 8 o'clock.

Here, the eating or painting event is likely to have started before dinner / before 8 o'clock; it is just the moment of finishing the apple / completing the picture that takes place after 8 o'clock.
} 


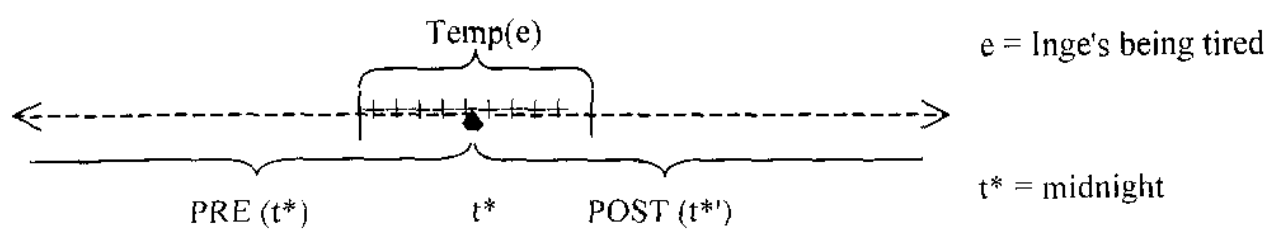

This is consistent with the semantics given in (8). (13a) conveys an assertion about J's playing the flute at some time before seven. It does not follow that he stops doing so before seven. Due to the fact that playing the flute is a homogeneous event, e may have a continuation within a time period that extends to the time after seven. Again, it is due to pragmatic reasoning that we tend to understand these utterances in a more restricted way: if someone tells us that Inge had spoken with Walter after breakfast, there is a conversational implicature that she started doing so after breakfast. However, this is not part of the semantic meaning conveyed by the sentence.

Bis $(z u)^{\prime}$ and seit share the relational information conveyed by vor / nach in that they also locate the THEME within the PRE-TIME / POST-TIME of the RELATUM.

(15) a. Jonathan joggte bis sieben Uhr.

Jonathan was jogging till seven o'clock.

b. Jonathan joggte seit sieben Uhr.

Jonathan was jogging since seven o'clock.

(15a) asserts that the time of Jonathan's jogging lasted (at least) till seven, (15b) that it least included the time immediately after seven. Bis ( $z u)$ T denotes a semi-open interval in PRE (T) including the terminal closure of PRE (T).

(16) bis (zu)

$\lambda \mathrm{T} \lambda$ e $\left[\right.$ Temp (e) $\left.\subseteq \operatorname{PRE}(\mathrm{T}) \& \operatorname{Temp}(\mathrm{e}) \supset^{*}\right]$, where

$\mathrm{e}$ is a homogeneous event and $t^{*}$ is the delimiting time between PRE (T) and T.

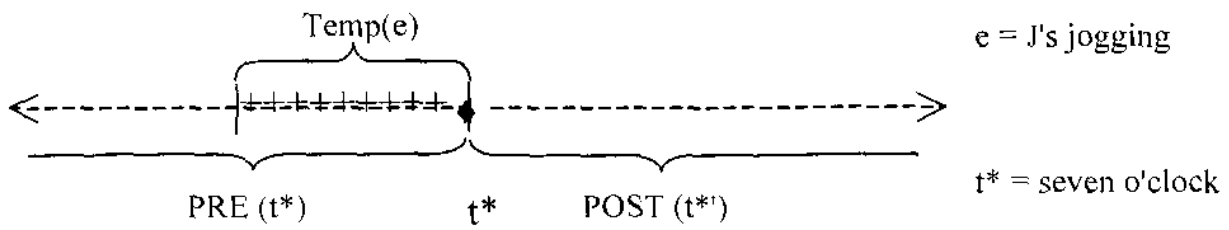

Seit $T$ denotes a semi-closed subsection of the POST-TIME including the initial closure of $\operatorname{POST}(\mathrm{T})$ :

(17) seit $^{8}$

$\lambda_{\mathrm{T}} \lambda_{\mathrm{e}}\left[\mathrm{Temp}(\mathrm{e}) \subseteq \operatorname{POST}(\mathrm{T}) \& \operatorname{Temp}(\mathrm{e}) \supseteq \mathrm{t}^{*}\right]$ where

$\mathrm{e}$ is a homogeneous event and $t^{*}$ is the delimiting time between POST (T) and T

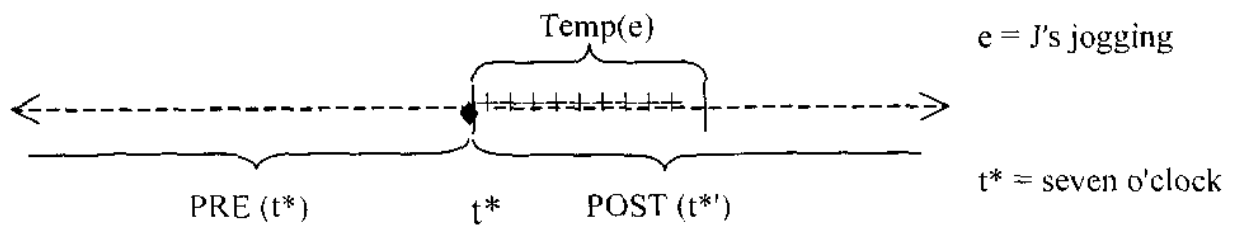

\footnotetext{
${ }^{7}$ Note, that bis is replaced by bis $z u$ when combined with determiner plus count noun - we consider this to be an allomorphy without semantic consequences.

${ }^{8}$ Seit, in fact, is more complicated than the other prepositions. For our purposes, however, it is enough to say that seit needs a punctual left side boundary as its RELATUM and a homogeneous THEME event.
} 
Both bis $z u$ and seit require homogeneous situations (states, activities) as THEMEs.

(18) a. Inge bleibt bis morgen zu Hause.

Inge stays at home until tomorrow.

b. Inge arbeitete bis zu der Konferenz an ihrem Vortrag.

Inge worked on her talk until the conference.

c. \#Inge schreibt ihr Papier bis zu der Konferenz.

Inge writes her paper until the conference.

d. \#Bis zum Abend kommt das Paket an.

Until the evening, the parcel arrives.

(19) a. Walter ist seit seinem Vortrag zu Hause.

Walter is at home since his talk.

b. Walter redet seit Mitternacht.

Walter is talking since midnight.

c. \#Seit der Konferenz schreibt Walter sein Papier.

Walter is writing his paper since the conference.

d. * Seit sieben Uhr kommt der Zug an.

Since seven o'clock, the train arrives.

(18c, d) are not strictly ungrammatical; accepting them, however, presupposes a reinterpretation of the matrix predicates as referring to the state resulting from Inge's writing the letter / from the package's arrival (18').

$\left(18^{\circ}\right)$ c. Inge wird ihr Papier bis zu der Konferenz geschrieben haben.

Inge will have written her paper until the conference.

d. Das Paket wird bis zum Abend angekommen sein.

The parcel will have arrived until the evening.

In the case of seit, accomplishments allow a re-interpretation in the sense of (19'). For achievements no such re-interpretation is possible.

(19') c. Seit der Konferenz arbeitet Walter an seinem Papier.

Since the conference, Walter is working on his paper.

d. * Seit sieben Uhr ist der Zug dabei, anzukommen.

Since seven o'clock, the train is arriving.

As bis and seit only occur with homogeneous situations (activities and states), the THEME event can always go on beyond the delimiting point:

(20) a. Inge und Walter redeten miteinander bis Mitternacht.

Inge and Walter talked to each other till midnight. 
b. Inge und Walter redeten miteinander seit Mitternacht. Inge and Walter talked to each other since midnight.

Being told that Inge and Walter talked to each other till midnight makes us infer that they stopped talking at midnight. Again, this inference is based on pragmatic reasoning (principle of relevance). A speaker telling us (20a) in reference to a situation where, in fact, Inge and Walter kept talking at midnight and afterwards, would refer to a temporal borderline of no relevance to the message conveyed.

To summarize: According to the two-level-approach to semantics, the representation of vor, nach, bis (zu) and seit just includes the contextually invariant meaning: Vor/bis (zu) on the one hand and nach/seit on the other hand locate the time of the THEME event before or after some delimiting point respectively. Furthermore, bis (zu) and seit require the THEME event to extend up to this point. Everything else is given by pragmatic (Gricean) principles, especially the principle of relevance. According to this principle, the expression of a temporal borderline should be relevant; a homogeneous THEME event is usually not considered to be part of a bigger event which extends beyond the delimiting point, accordingly. In the case of vor / nach the same principle makes us conclude that the THEME is in proximal distance to the RELATUM.

The "nature" of the - semantically required - delimiting point is not given by the prepositions either; hence, in the case of a protracted RELATUM it has to be inferred. This inference procedure, however, is not only determined by pragmatic principles: In the next section we will show that it crucially depends on the event structure of the RELATUM.

\subsection{Vor/bis/nach/seit with event nominals: How to find the delimiting point}

We have shown that vor/bis/nach/seit always need a point in time to anchor the THEME event. Our claim is that in the case of a protracted RELATUM this delimiting point has to be inferred from the given event structure (Aktionsart). Roughly speaking, it is only those event structure points which are conceptually prominent that can be chosen as delimiting points. Hence, the anchoring of temporal prepositions can give us important insights into the relative salience of event structure. In this section, we will concentrate on ung-nominals. Sometimes we will also refer to other event or state nouns. First note that the RELATUM event must always be a situation which can be closed.

(21) a. Vor/Bis zu seinem Bankraub war Hans arm.

Before/Until robbing a bank, John was poor.

b. *Vor/Bis zu seiner Klugheit war Hans arm.

Before/Until being wise, John was poor.

c. Nach/Seit dem Lotteriegewinn war Hans glücklich.

After/Since his lottery prize, John was happy.

d. $*$ Nach/Seit seiner Bescheidenheit war Hans reich.

After/Since being modest, John was rich.

An open event with no conceivable closure may not serve as RELATUM as it does not offer a delimiting point. A condition for the use of vor/nach/bis $(z u) /$ seit is the possibility of extracting such a point from the RELATUM's event structure. How this point in time is inferred for vor/bis on the one hand and nach/seit on the other hand will be shown in 3.2.1 and 3.2.2, respectively. 


\subsubsection{Vor and bis}

Both vor and bis require a right side boundary for their THEME event. If the RELATUM is an achievement nominalization like Ablehnung (,refusal“) no ambiguities arise. Being telic, achievements have a culmination point: this is the point which corresponds to the resultant state's onset. As achievements lexicalize a punctual change of state, their culmination point and their proper onset coincide. Hence, achievements offer just one point which can be used as a boundary:

\section{Achievements with vor and bis:}

(23) Vor/bis zu der Ablehnung des Angebots war sie glücklich.

Before/until the offer was refused she was happy.

\section{Delimiting point $t^{*}=$ culmination point}

vor:

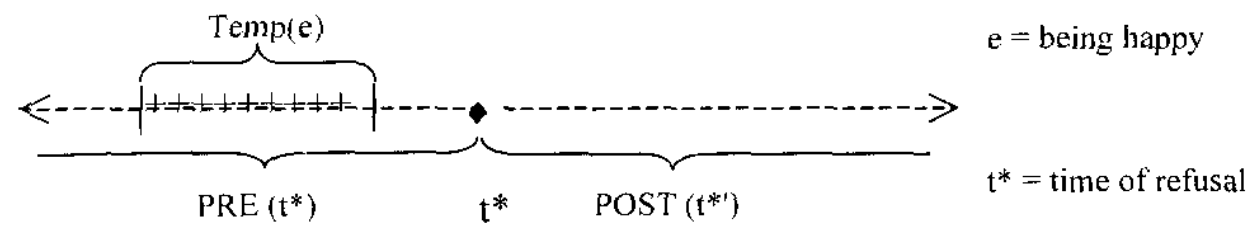

bis:

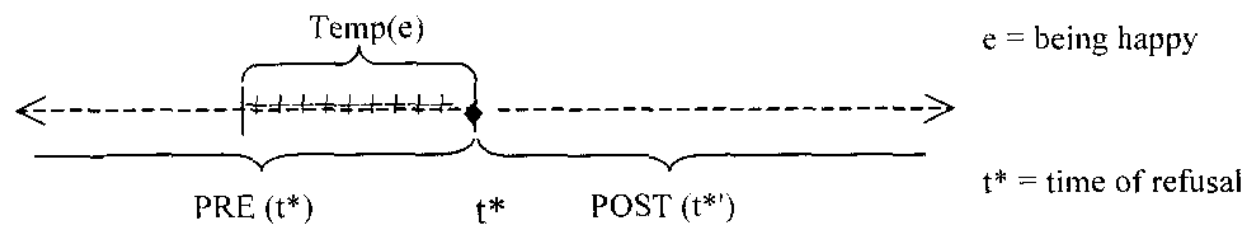

Things get more complicated if the nominal's event structure provides more than one point. In the case of vor and bis, we are approaching the time of the RELATUM event from the left side. The easiest thing, of course, would be to take the onset of the RELATUM event as delimiting point $t^{*}$. This seems to hold for activities:

(24) $v o r / b i s$ with activity nominals:

a. Vor/bis zu der Verfolgung Öcalans freute sie sich auf die Reise.

Before/until the persecution of Öcalan she was looking forward to the journey.

b. Vor/bis zu der Wanderung rauchte sie.

Before/until the walk she was smoking.

\section{Delimiting point $t^{*}=$ initial closure of the activity:}

vor:

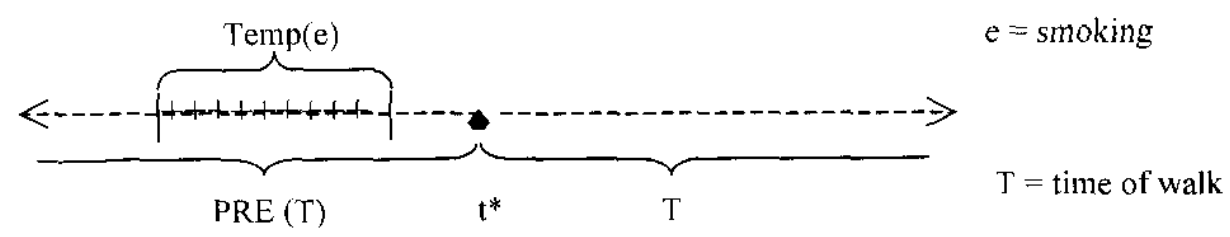


bis:

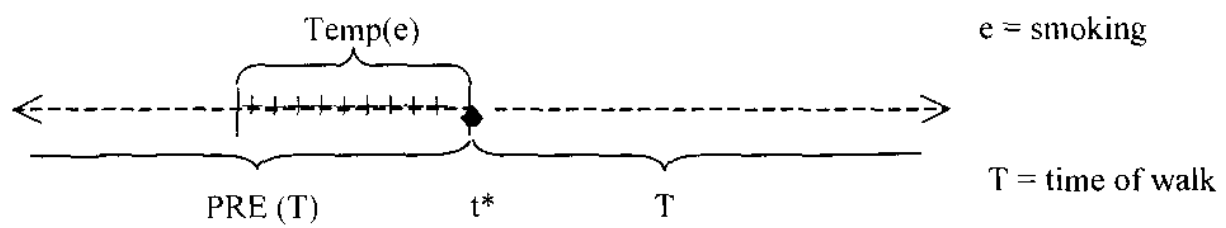

Accomplishment nominals, however, show a different behaviour. We can either choose the onset or the culmination point:

(25) vor/bis with accomplishments:
a. Vor/bis zu
Before/until der Auswertung der Akten rauchte sie. the evaluation of the files she was smoking.
a*. Vor/bis zu der Auswertung der Akten gibt es keine Klarheit über dieses Problem.
Before/until the evaluation of the files nothing is clear about this problem.
b. Vor/bis zu der Erbauung der Kathedrale muss das nötige Geld gefunden werden.
Before/until the building of the cathedral the necessary money has to be
found.
$b^{6}$. Vor/bis zu der Erbauung der Kathedrale war die Stadt total unbekannt. Before/until the building of the cathedral the town was totally unknown.
c. Vor/bis zu Before/until der Heilung des Patienten meditierte der Arzt. the patient was cured the doctor was meditating.
c. Vor/bis zu Before/until der Heilung des Patienten gab es keine Hoffnung.
d. Vor/bis zu Before/until der Lösung des Problems trank sie Kaffee. the solution of the problem she was drinking coffee.
$\mathrm{d}^{6}$. Vor/bis zu Before/until der Lösung des Problems waren alle verzweifelt. the solution of the problem everybody was desperate.

It depends highly on the context which delimiting point one would actually choose. Normally in (a) one would take the onset, in ( $\mathrm{a}^{6}$ ) the culmination point, and so on.

However, one might ask if there are indeed only two readings. In other words: Is it possible to have intermediate readings? In the case of bis this seems to be excluded. Consider bis-phrases modified by fast ('almost'):

(26) a. Sie trank fast bis zur Auswertung der Akten Kaffee.

She was drinking coffee almost until the evaluation of the files.

b. Sie rauchte fast bis zur Lösung des Problems.

She was smoking almostuntil the solution of the problem. 
These sentences assert that the THEME event ended just before the RELATUM's onset or just before its culmination point. Other readings are excluded. We may conclude that bisphrases with accomplishment nominals have just two distinct readings.

Things are less evident with vor. Here, the THEME event does not have to extend up to the delimiting point $t^{*}$; it has to happen just some time before $t^{*}$. Hence, the following sentences seem to be somehow vague:

(27) a. Sie trank vor der Auswertung der Akten Kaffee.

She was drinking coffee before the evaluation of the files.

b. Sie rauchte vor der Lösung des Problems.

She was smoking before the solution of the problem.

c. Meine kleine Tochter malte vor der Auswertung der Akten ein Bild.

My little daughter painted a picture before the evaluation of the files.

d. Der Politiker verschwand vor der Auswertung der Akten.

The politician disappeared before the evaluation of the files.

Obviously, in one reading the coffeedrinking, smoking, painting or disappearing took place some time before the RELATUM's onset. The other reading means that it happened before the culmination point $t^{*}$. Of course, in this second reading it can have happened at any time before $t^{*}$ : hence, it could have happened before all the intermediate points as well.

At this point it is interesting to consider negation. If vor combines a negated THEME event with a TADV we obtain the reading that an event of this kind did not take place before the specific time denoted by TADV:

(28) Vor 5 Uhr rauchte sie nicht.

Before 5 o'clock she did not smoke.

Now, if the RELATUM is an accomplishment nominal, there are definitely only two readings. The onset and the culmination point - but no intermediate points - can be taken as delimiting point:

(29) Vor der Auswertung der Akten rauchte sie nicht.

Before the evaluation of the files she did not smoke.

There is a similar effect if we use adverbials indicating that the THEME event does not end before the delimiting point:

(30) a. Ich rauchte vor der Auswertung der Akten pausenlos,

I smoked non-stop before the evaluation of the files.

b. Vor der Lösung des Problems rauchte sie pausenlos.

Before the solution of the problem she smoked non-stop.

We conclude that there is a real ambiguity, if a vor/bis-PP takes an accomplishment nominal as its RELATUM. This ambiguity is shown in the following diagrams - the paraphrases of e1, $\mathrm{e} 2$ and $\mathrm{T}$ correspond to (25a): 
(31)

vor:

variant (i)

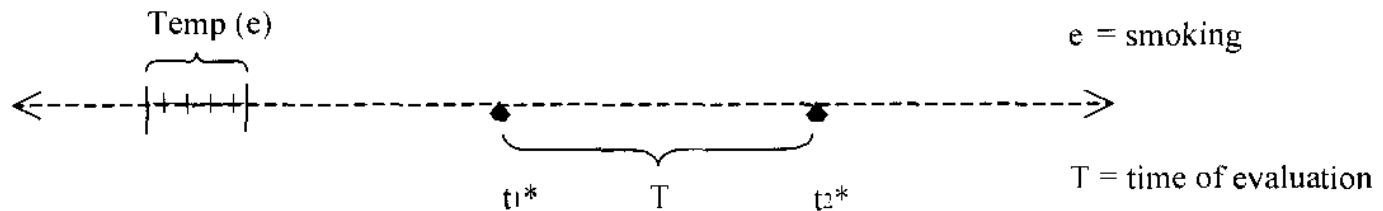

variant (ii)

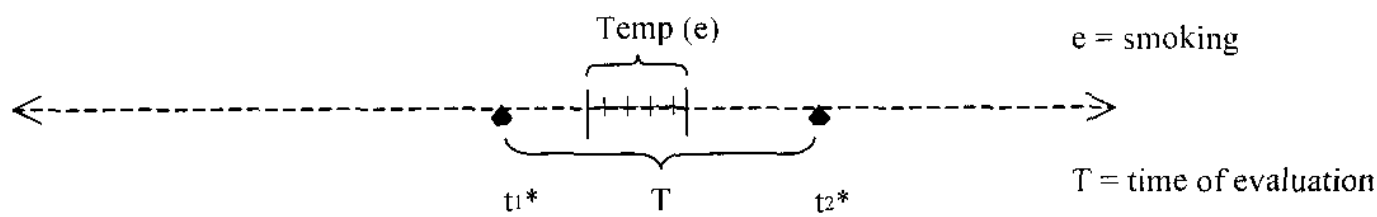

(32) bis:

variant (i)

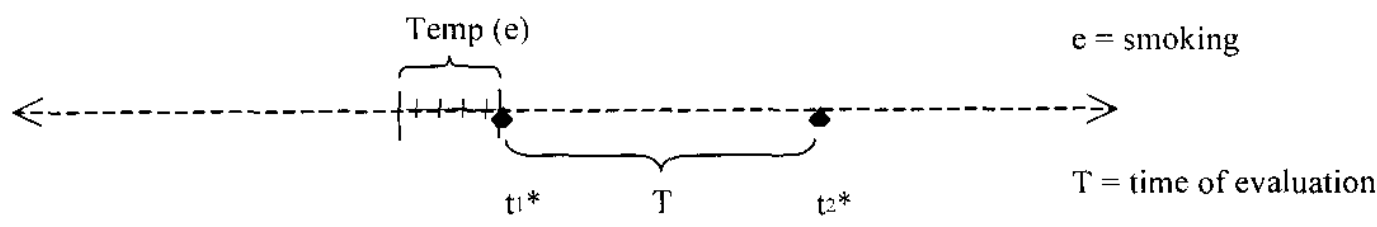

variant (ii)

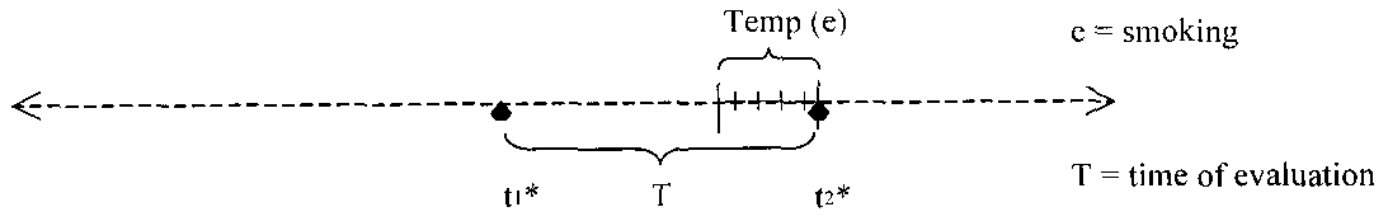

In the case of activity RELATA, on the other hand, there is only one reading. To explain this difference it is helpful to consider the conjunctional counterparts of the prepositions. If they embed a clause with an accomplishment verb, the conjunctions bevor and bis can always select two anchoring points. These two readings are made explicit by means of tense. The onset reading is indicated by a present/simple past, the culmination point reading by a perfect/past perfect:

(33) a. Bevor man die Akten auswertete,

Before one evaluated the files, ...

$a^{c}$. Bevor man die Akten ausgewertet hatte,

Before one had evaluated the files, ...

b. Er trank Kaffee, bevor er den Brief schrieb.

He was drinking coffee before he wrote the letter.

$b^{*}$ Ich gehe nicht, bevor du den Brief geschrieben hast.

I do not go before you have written the letter. 
(34) a. Bis man die Akten auswertete, Until one evaluated the files, ...

$a^{6}$ Bis man die Akten ausgewertet hatte, Until one had evaluated the files, ...

b. Maria wartete, bis Peter den Brief schrieb.

$\mathrm{M}$. was waiting until Peter wrote the letter.

$b^{c}$. Maria wartete mit dem Essen, bis Peter den Brief geschrieben hatte. (Herweg 1990:307 (10c))

M. was waiting with the dinner until Peter had written the letter.

c. Ich wartete hinter der geriegelten Tür, bis man das Donnern einer startenden Maschine hörte.

I was waiting behind the locked door until I heard the thundering of the take-off of a plane.

c* Ich wartete hinter der geriegelten Tür, bis man das Donnern einer startenden Maschine gehört hatte. (Herweg 1990:308 (12b))

I was waiting behind the locked door until I had heard the thundering of the takeoff of a plane.

If used with achievement verbs, both constructions don't really differ in meaning:

(35) a. Ich bedrängte ihn so lange, bis er mein Angebot annahm/angenommen hatte. I pressurized him until he accepted/had accepted my offer.

b. Ich will dich nicht mehr sehen, bevor du diesen Vorschlag definitiv ablehnst/abgelehnt hast.

I do not want to see you anymore before you refuse/have refused this proposal definitely.

According to Herweg (1990:237), a present perfect/past perfect in bevor-clauses is quite rare with achievements; this could be due to its semantic equivalence with a present/simple past. In the case of activities, however, a perfect tense seems to be really deviant:

(36) a. Bevor man Öcalan verfolgte, ...

Before one persecuted Öcalan, ...

$\mathrm{a}^{a}$. ??Bevor man Öcalan verfolgt hatte, ...

Before one had persecuted Öcalan, ...

b. Bis man Öcalan verfolgte, ...

Until one persecuted Öcalan, ...

b'. ??Bis man Öcalan verfolgt hatte, ...

Until one had persecuted Öcalan, ... 
Obviously, this deviance is related to the event structure of activities: Whereas accomplishments have a culmination point, activities do not provide a prominent termination which could be used as a limit.

Let us turn again to the corresponding prepositions used with eventive nouns. Here, the intended interpretation cannot be made explicit by tense. Nevertheless, the different readings match with those of the corresponding conjunctional clauses. As we have shown, there are no ambiguities for achievements. Although activity nominals are durative, they do not allow for more than one reading either: Obviously, they provide just one prominent delimiting point: their onset. We conclude that only accomplishments are ambigous with respect to the delimiting point $t^{*}$ : Depending on the context, one can choose either the onset or the culmination point.

Stative RELATA behave like activities. When the temporal conjunctions bevor/bis are used with stative verbs, there is always a reinterpretation procedure necessary (cf. Herweg 1990). The most likely case is that the state itself is reinterpreted in an ingressive manner: ${ }^{9}$

(37) a. ?Maria rief an bevor Hans im Bett lag. (Herweg 1990:236 (4b))

M. telephoned before $H$. was lying in bed.

$=$ Maria telephoned before Hans went to bed.

b. Maria wartete mit dem Essen, bis Peter am Tisch saß. (Herweg 1990:307 (10b))

M. waited with dinner until Peter was sitting at the table.

$=$ Maria waited with dinner until Peter sat down.

Herweg claims that this reinterpretation procedure is due to the fact that the conjunctions bevor and bis always need a clear-cut point in time (1990:236). We need the same kind of reinterpretation if the corresponding prepositions are used with state nominals:

\section{(38) vor/bis with state nominals:}

a. Vor/bis zu der offiziellen Duldung versteckte Sabine ihr Krokodil.

Before/until the official toleration Sabine was hiding her crocodile.

b. Vor/bis zu der Belagerung verließen Tausende die Stadt.

Before/until the siege thousands left the town.

c. Vor/bis zu ihrer Krankheit war sie ein fröhlicher Mensch.

Before/until her illness she was a cheerful person.

We conclude that stative RELATA are possible, provided they can be reinterpreted in an ingressive manner. ${ }^{10}$ Hence, it is quite natural that vor/bis occur with resultant-state-

\footnotetext{
${ }^{4}$ Whereas the conjunction bis can only be used with a temporal meaning, Herweg notes that bevor is very often reinterpreted in a non-temporal manner. This holds for states as well as for all the other Aktionsarten (cf. Herweg 1990:244 (12)):

(i) Bevor Peter den weiten Weg zu Fuß geht, fährt er (lieber) mit dem Auto.

Before P. walks the long way he (rather) goes by car.

(ii) Bevor ich das glaube, fresse ich (lieber) einen Besen.

Before I believe that I (rather) eat a broom.

Such an interpretation does not seem to be possible for the corresponding preposition vor:

(iii) ??Vor einem Ausflug mit dir bleibe ich (lieber) zu Hause.

Before a trip with you I (rather) stay at home.

${ }^{1}$ Note that psychological state nouns, being open events without an initial closure, hardly allow for an ingressive reinterpretation:

(i) ??Vor/??'Bis zu ihrer Liebe zu Carlo hatte sie keine Probleme. Before/Until her love to Carlo she had no problems.
} 
RELATA. Here the delimiting point corresponds to the culmination point of the preceding event."

(39) vor/bis with resultant state nominals:

Vor/bis zu der dreimonatigen Absperrung konnte man auf der Straße fahren.

Before/until the blocking off which went on for three months one could drive on the street.

(40) vor: Delimiting point $t^{*}=$ culmination point (= onset of the resultant state):

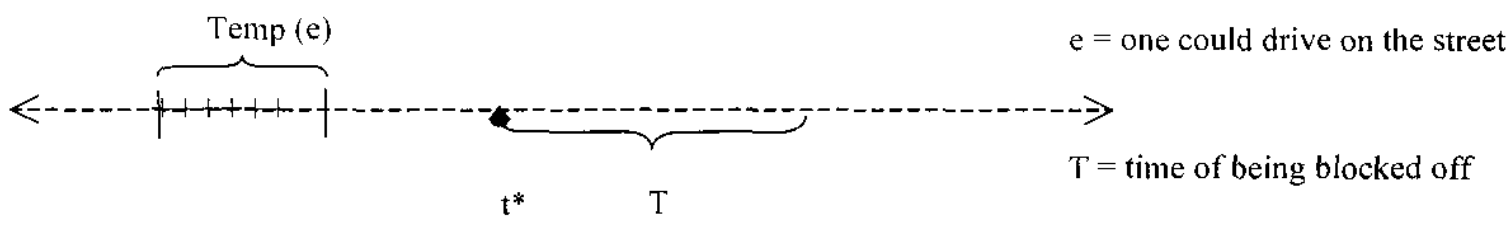

\section{bis: Delimiting point $t^{*}=$ culmination point (= onset of the resultant state):}

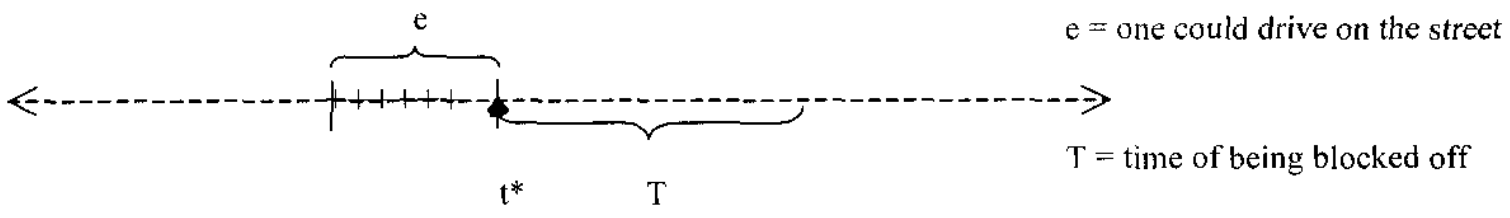

Our conclusion is that vor and bis always need a right side delimiting point. Normally, they take the next one available, e.g. the RELATUM's onset. In the case of accomplishments, however, it is also possible to use the culmination point. This corresponds exactly to the

(ii) ??Vor/??Bis zu ihrer Bewunderung für den Fernsehstar war sie ganz normal.

Before/Until her admiration for the TV star she was quite normal.

There seem to be some counterexamples like the following:

(iii) Vor/bis zu der Bewunderung des Ausblicks unterhielten sie sich.

Before/until the admiration of the panorama they talked.

(iv) Vor/bis zu der Verehrung der griechischen Götter liebten die Römer Naturgottheiten.

Before/until the worship of the Greek gods the Romans loved gods of nature.

We assume that here the nominals don't refer to real states but to activities; Verehrung for example can be understood as the ceremony involved with religious cults. Hence, real psychological state nouns cannot appear as a RELATUM to temporal prepositions. However, we have to leave open why an ingressive reinterpretation seems to be much better for psychological state verbs than for the corresponding nominals:

(v) Bevor/Bis sie Carlo liebte, hatte sie keine Probleme.

Before/Until she loved Carlo she had no problems.

(vi) Bevor/Bis sie diesen Fernsehstar bewunderte, war sie eigentlich ganz normal.

Before/Until she admired this TV star she was quite normal.

"In the case of nouns like Absperrung 'blocking off' we distinguish an eventive reading and a resultant state reading (cf. Ehrich/Rapp 2000):

(i) Event nominalization:

die um 12 erfolgte Absperrung des Geländes the blocking off of the area at 12 (punctual time specification)

(ii) Resultant state nominalization:

die dreimonatige Absperrung des Geländes the blocking off of the area for three months (durative time specification) 
conditions for the temporal conjunctions bevor and bis: An endpoint reading - here indicated by tense - can only be chosen if this end point is provided by the culmination point of the action in question. Obviously, the interpretation for both the prepositional and the conjunctional use is determined by event structure properties of the RELATUM.

\subsubsection{Nach and seit}

In contrast to vor and bis, nach and seit require a left side delimiting point. What happens if these prepositions take an event nominal as their RELATUM? It is quite clear that it should always be possible to select the termination of the noun's event structure. The question is whether it is also possible to take the onset. Consider nach and seit with achievements, activities, accomplishments and states:

(41) nach/seit with achievement nominals:

$\mathrm{Nach} /$ seit der Ablehnung des Angebots war sie glücklich.

After/since the refusal of the offer she was happy.

(42) $\boldsymbol{n a c h} /$ seit with activity nominals:

$\mathrm{Nach} /$ seit der Verfolgung Öcalans waren viele Menschen besorgt. After/since the persecution of Öcalan many people were worried.

(43) nach/seit with accomplishment nominals:

a. Nach/seit der Auswertung der Akten trank sie Kaffee.

After/since the evaluation of the files she was drinking coffee.

a‘ Nach/seit der Auswertung der Akten war das Problem gelöst.

After/since the evaluation of the files the problem was solved.

b. Nach/seit der Erbauung der Kathedrale klagten die Bürger über den Lärm. After/since the construction of the cathedral the citizens complained about the noise.

b'. Nach/seit der Erbauung der Kathedrale war die Stadt bekannt. After/since the construction of the cathedral the town was well known.

(44) $n$ ach/seit with state nominals:

a. Nach/seit der offiziellen Duldung wohnte das Krokodil im Gartenhaus. After/since the official toleration the crocodile lived in the garden shed.

b. Nach/seit der Belagerung verließen Tausende die Stadt. After/since the siege thousands left the town.

(45) $\boldsymbol{n a c h} /$ seit with resultant state nominals:

$\mathrm{Nach} /$ seit der dreimonatigen Absperrung des Gebiets erholten sich die Wasservögel. After/since the blocking off of the area which went on for three months the water birds recovered.

For achievement nominals being punctual in nature, there is only one possibility to anchor the temporal prepositions. For the other Aktionsarten, there is an interesting difference between nach and seit. The nach-examples have only one reading: The delimiting point always corresponds to the termination. The seit-examples, on the other hand, are ambiguous, as they do not only allow for a termination but also for an onset reading: 


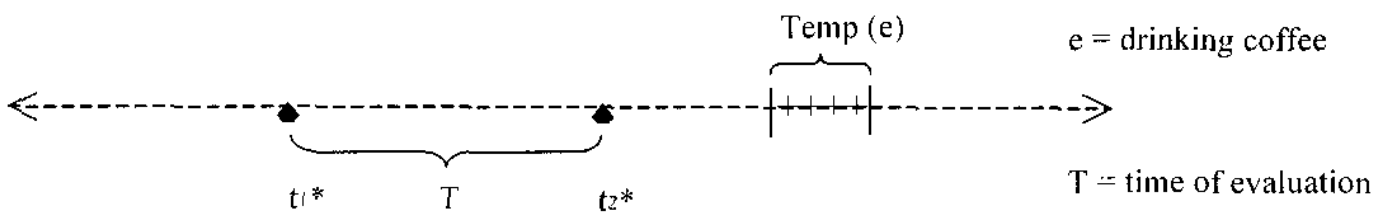

(47) seit: Delimiting point $t^{*}=$ onset or termination of the event: variant (i)

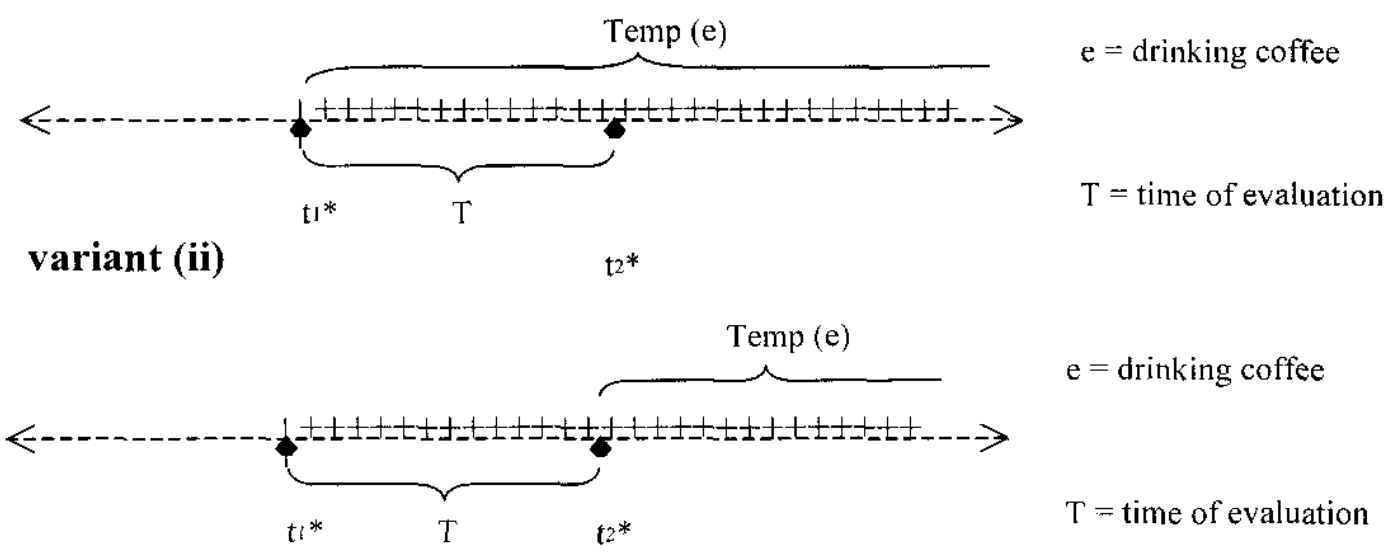

However, one might ask if this analysis is the only possible one. In 3.1 we argued that a homogeneous THEME can always be part of a bigger event of the same kind which goes beyond the delimiting point:

(48) a. Sie trank vor 7 Uhr Kaffee (und auch danach).

She was drinking coffee before 7 o'clock (and did so afterwards, too).

b. Sie trank bis 7 Uhr Kaffee (und auch danach).

She was drinking coffee until 7 o'clock (and did so afterwards, too).

c. Sie trank nach 7 Uhr Kaffee (und auch schon zuvor).

She was drinking coffee after 7 o'clock (and did so already before).

d. Sie trank seit 7 Uhr Kaffee (und auch schon zuvor).

She was drinking coffee since 7 o'clock (and did so already before).

In (48), the delimiting point just gives a potential borderline for the subevent. It is a conversational implicature that we consider this borderline to be relevant, e.g. to delimit the whole event - however in the case of homogeneous events this is not a necessary condition.

We have seen that seit requires a homogeneous THEME. Hence, we might argue that, here, the delimiting point is always given by the termination of the RELATUM event. Being homogeneous, the THEME could nevertheless be part of a bigger THEME extending up to the onset of the RELATUM event. There would then be no need to claim an ambiguity for the temporal anchoring of seit-THEMEs. The delimiting point would always be given by the termination, and the onset reading would just result from cancelling the conversational implicature that this temporal borderline is a relevant one. 
However, this explanation does not seem appropriate for seit. Again, it is interesting to compare nach and seit, when used with homogeneous RELATUM events. In the case of nach the RELATUM's termination clearly is considered to be the relevant borderline for the whole THEME event. This implicature can be cancelled in two ways:

(49) a. Nach dem Frühstück sprachen Lena und Klaus miteinander (wie auch schon während des Frühstücks).

After breakfast Lena and Klaus talked to each other and they did so already during breakfast.

b. Nach dem Frühstück sprachen Lena und Klaus miteinander (wie auch schon vor dem Frühstück).

After breakfast Lena and Klaus talked to each other and they did so already before breakfast.

In both examples there are two talking events. In (49a), however, these two events can be part of one long talking event which goes beyond the delimiting point given by nach, e.g. the termination of breakfast. In ( $49 \mathrm{~b})$ such a reading is excluded: The two talking events need to be distinct: they are separated by the protracted RELATUM breakfast.

Now consider seit when used in the same contexts:

(50) a. ??Seit dem Frühstück sprachen Lena und Klaus miteinander und auch schon während des Frühstücks.

Since breakfast Lena and Klaus talked to each other and they did so already during breakfast.

b. Seit dem Frühstück sprachen Lena und Klaus miteinander und auch schon vor dem Frühstück.

Since breakfast Lena and Klaus talked to each other and they did so already before breakfast.

The cancelling procedure in (50a) is rather odd for seit. According to the context, seit takes the RELATUM's onset as delimiting point quite naturally. Hence, there is no implicature like "They did not talk to each other before the end of breakfast" and no need to cancel it. On the other hand, seit always yields the implicature that the THEME event does not go beyond the RELATUM's onset. As usual, it is possible to cancel this implicature (50b). Now, in contrast to (49b), (50b) can have the meaning that Lena and Klaus talked to each other without an interruption before and after the beginning of breakfast. If seit always had to take the RELATUM's termination as its delimiting point this reading would have to be excluded. We conclude that seit - but not nach - may take the RELATUM's onset as its delimiting point quite naturally.

Again, we have to ask ourselves whether the seit-construction is really ambiguous instead of being just vague. The negation test and the use of ,extending adverbs" prove very clearly that there are indeed only two readings, e.g. two delimiting points:

(51) a. Seit der Verfolgung Öcalans gab es keine Demonstration mehr hier.

Since the persecution of Öcalan there were no more demonstrations.

b. Seit der Auswertung der Akten rauchte der Büroangestellte ununterbrochen.

Since the evaluation of the files the employee smoked non-stop. 
The onset reading means that there were no demonstrations since the beginning of the persecution, the termination reading that there weren't any after the end of this persecution. Intermediate readings are not possible.

We conclude that - in contrast to nach - seit is ambiguous when used with protracted RELATUM events. Now, quite obviously, the unmarked interpretation relates to event structure properties. Activities and states (Verfolgung 'persecution', Duldung 'toleration') do not have a structurally prominent termination - hence, it is clear that they are good candidates for an onset reading. For accomplishments (Auswertung 'evaluation'), on the other hand, the culmination point is most salient in event structure: It follows that the termination interpretation is quite natural for them. However, the actual choice of the delimiting point can vary according to discourse and / or situative context. In $(52 \mathrm{a}, \mathrm{b})$ we would presumably take the onset of Ferien 'holidays', Frühstück 'breakfast' as delimiting point, in $(52 \mathrm{c}, \mathrm{d})$ it is the termination:

(52) a. Seit den Ferien hat sie keinen ihrer Schüler mehr gesehen.

Since the holidays she has not seen any of her pupils.

b. Seit dem Frühstück sitzt Jonathan im Speisesaal.

Since breakfast $\mathrm{J}$, is sitting in the dining room.

c. Seit den Ferien zeigt er ein viel besseres Lernverhalten.

Since the holidays he shows a much better behaviour in studying.

d. Seit dem Frühstück joggt er.

Since breakfast he is jogging.

World knowledge tells us that it is normal to be sitting in the dining room but uncommon (albeit not impossible) to be jogging while having breakfast. We naturally interpret (b) and (d) as saying that Jonathan was sitting in the dining room from the beginning of his breakfast, but that he started jogging after having finished breakfast. Similar reasoning holds for (a) and (c): it is common not to see one's pupils during the holidays but it is less common to be learning during the holidays; thus we assume the onset reading for (a) and the termination reading for (b). To sum up, prepositional seit offers two anchoring points in the case of protracted RELATA. According to the event structure one of these points is more salient; however it depends on contextual and pragmatic reasons which one is actually chosen. Temporal nach on the other hand is always restricted to the terminal closure reading.

Apart from looking at the nominalizations it is also interesting to look at the clausal counterparts introduced by temporal conjunctions nachdem/seit(dem). Nachdem obligatorily selects a resultative tense, e.g. a perfect or a past perfect (c.f. Herweg 1990:217ff.). The anchoring point always corresponds to the terminal closure of the RELATUM. This holds for any Aktionsart: ${ }^{12}$

\footnotetext{
${ }^{12}$ As Herweg notes, nachdem sometimes combines with a state in a non-resultative tense; however, he proves that these examples have to be reinterpreted: Either the preposition assumes a non-temporal, causative meaning (i) or the state assumes an ingressive reading, e.g. it refers to an immediately preceding event (ii), sometimes lexically indicated by an adjectival passive (iii):

(i) Nachdem du jetzt Klavier lernen willst, verkaufe ich deine Flöte wieder. After (-as) you want to learn the piano now, I sell your flute again.

(ii) Nachdem er an der frischen Luft war, fühlte er sich besser. (Herweg 1990:218 (3)) After he had breathed fresh air, he felt better.

(iii) Nachdem die Bilder befestigt waren, kümmerten wir uns um die Spiegel. After the pictures were fixed we looked after the mirrors.
} 
(53) a. ??/*Nachdem sie das Angebot ablehnte,

After she refused the offer,

a'. Nachdem sie das Angebot abgelehnt hatte,

After she had refused the offer,

b. $\quad$ ??*Nachdem er die Straße überquerte, brach er zusammen. (Herweg 1990:224

(10a))

After he crossed the street, he broke down.

b`. Nachdem er die Straße überquert hatte, brach er zusammen. (Herweg 1990:224

(11a))

After he had crossed the street, he broke down.

c. ??/*Nachdem er schwamm, brach er zusammen.

After he swam, he broke down.

$c^{c}$. Nachdem er geschwommen war, brach er zusammen.

After he had swum, he broke down.

d. $\quad ? ?{ }^{*}$ Nachdem das Gebiet drei Monate lang abgesperrt war, ...

After the area was blocked off for some months, ...

$d^{c}$. Nachdem das Gebiet drei Monate lang abgesperrt gewesen war, ...

After the area had been blocked off for some months, ...

In contrast to this, conjunctional seit(dem) can refer to the onset or to the termination of a protracted RELATUM:

(54) a. Seitdem er in Berlin gewohnt hat, ist er viel netter.

Since he had lived in Berlin, he is much nicer.

a'. Seitdem er in Berlin wohnt, ist er viel netter.

Since he is living in Berlin, he is much nicer.

b. Seitdem er bei Daimler gearbeitet hat, ist er reich.

Since he had worked at Daimler, he is rich.

$b^{c}$. Seitdem er bei Daimler arbeitet, ist er glücklich.

Since he is working at Daimler, he is happy.

c. Seitdem sie dieses Buch gelesen hat, ist sie sehr bedrückt.

Since she had read this book, she is very depressed.

c‘. Seitdem sie dieses Buch liest, ist sie sehr bedrückt.

Since she is reading this book, she is very depressed. 
The termination reading requires a perfect/past perfect, the onset reading a simple tense. ${ }^{13}$ Note that the onset reading needs to be interpreted in a progressive manner. In the case of punctual RELATUM events, onset and termination coincide. This excludes a progressive reading, hence they always require a perfective tense:

(55) a. Seitdem er aus dem Haus getreten war, beobachtete ich ihn.

Since he had left the house I was watching him.

a'. *Ich beobachtete ihn, seitdem er aus dem Haus trat.

I was watching him since he left the house.

b. Seit(dem) sie das Angebot abgelehnt hatte, ...

Since she had refused the offer,..

b'. *Seit(dem) sie das Angebot ablehnte, ...

Since she refused the offer, ..

We conclude that the conjunctions nachdem and seit(dem) behave like their prepositional counterparts: nach (dem) is restricted to the termination reading, whereas seit(dem) can have the onset and the termination reading. To sum up, nach(dem) is not really informative as it never goes inside the event structure of the RELATUM. Seit(dem), on the other hand, shows us that the onset of the RELATUM is always salient: It can be picked up as a delimiting point though the termination would be closer to the THEME event.

\section{Conclusion}

The SF-representation of temporal prepositions specifies their invariant meaning, e.g. the relation between the THEME event in question and a specific period in time. Während expresses the inclusion of the THEME in a protracted period, vor and bei lexicalize anteriority with respect to a delimiting point, nach and seit posteriority. If the RELATUM of the preposition is an event or state nominal, the required period or point in time has to be inferred. As we have shown with respect to ung-nominalizations, this inference procedure gives us important insights into the event structure of the RELATUM.

First of all, our investigation supports the claim that the event structure of the base verb is preserved in ung-nominalizations. This is quite clear in the case of während: requiring a protracted time span it can be combined with those ung-nominals which inherit a protracted event structure from their base, e.g. activities, accomplishments or states - but not achievements. Vor, bis and seit, on the other hand, also show that the difference between accomplishments, achievements, activities and states is not neutralized in ungnominalizations. The temporal ambiguities are always restricted to specific Aktionsarten: seit yields an ambiguity if combined with nominalizations based on durative verbs, vor and bis are only ambiguous if combined with nominalizations based on accomplishment verbs. Hence, the data presented in this paper are in a line with Ehrich/Rapp (2000), where it was claimed that eventive $u n g$-nominals preserve the event structure of their base verb.

Furthermore, the temporal prepositions which require a point in time as their RELATUM give us important insights into the relative prominence of event structure. Vor and bis need a right side boundary. Normally, the initial closure of the event - as the nearest point - is selected. The interesting thing is that, in the case of accomplishments, we can also take the termination point. This is impossible for activities and states: the termination of an

\footnotetext{
${ }^{13}$ In contrast to these examples Herweg (1990) claims that - like nachdem - the temporal conjunction seitdem always requires a perfective tense.
} 
event is only prominent if it is a culmination point. Seit, on the other hand, needs a left side boundary: it is obvious that we can take the termination point of the RELATUM event. But the interesting thing is that for all protracted events we can also take the onset - obviously, because it is always prominent in event structure. In sum, ambiguities arise if there is a prominent point in the event structure which is not identical to the next boundary acessible. In the case of activities and states this only holds for seit: Here, the next delimiting point is the termination, but the most prominent point in event structure is the onset of the activity/state. In the case of accomplishments, vor, bis and seit yield an ambiguity. This is due to the fact that both the onset and the culmination point are salient in the event structure of accomplishments; hence there is always a prominent point which does not correspond to the next delimiting point required by the preposition.

\section{References}

Bierwisch, Manfred (1983): Semantische und konzeptuelle Repräsentation lexikalischer Einheiten. In: Rudolf Růžička/Wolfgang Motsch (eds.): Untersuchungen zur Semantik. Berlin: Akademie-Verlag (= Studia grammatica 22), 61-99.

Bierwisch, Manfred (1988): On the Grammar of Local Prepositions. In: Manfred Bierwisch/Wolfgang Motsch/Ilse Zimmermann (eds.): Syntax, Semantik und Lexikon. Berlin: Akademie-Verlag (= Studia Grammatica 29), 1-65.

Bierwisch, Manfred/Lang, Ewald (eds.) (1989):Dimensional Adjectives: Grammatical Structure and Conceptual Interpretation. Berlin/Heidelberg/New York: Springer.

Ehrich, Veronika (1992): HIER und JETZT. Studien zur lokalen und temporalen Deixis. Tübingen: Niemeyer.

Ehrich, Veronika/Rapp, Irene (2000): Sortale Bedeutung und Argumentstruktur: ung-Nominalisierungen im Deutschen. Zeitschrift für Sprachwissenschaft 19/2, 245-303.

Herweg, Michael (1989): Ansätze zu einer Beschreibung topologischer Präpositionen. In: Christa Habel et al. (eds.): Raumkonzepte in Verstehensprozessen. Interdisziplinäre Beiträge zu Sprache und Raum. Tübingen: Niemeyer, 99-127.

Herweg, Michael (1990): Zeitaspekte: die Bedeutung von Tempus, Aspekt und temporalen Konjunktionen. Wiesbaden: Deutscher Universitätsverlag.

Klein, Wolfgang (1990): Raumausdrücke. Überall und nirgendwo. Subjektive und objektive Momente in der Raumreferenz. In: W. Klein (ed.): Sprache und Raum. Zeitschrift für Literaturwissenschaften und Linguistik 20/78, 9-42.

Klein, Wolfgang (1994): Time in Language. London: Routledge.

Lang, Ewald (1993). The Meaning of German Projective Prepositions: a Two-level Approach. In: C. ZelinskyWibbelt (ed.): The Semantics of Prepositions. From Mental Processing to Natural Processing. Berlin / New York : de Gruyter, $249-291$.

Maienborn, Claudia (2001): Die logische Form von Kopula-Sätzen. Habilitationsschrift, Humboldt-Universität zu Berlin.

Rapp, Irene (1996). Partizipien und semantische Struktur: zu passivischen Konstruktionen im 3 . Status. Tübingen: Stauffenburg.

Rapp, Irene (2001a): Linkingsteuerung im Verbalbereich: Welche Bedeutungsaspekte sind relevant? LAB 76, Universität Leipzig, 185-219.

Rapp, Irene (2001b): Argumentstruktur und Erstgliedinterpretation bei deverbalen Derivaten - ein semantikbasierter Ansatz. To appear in: Folia Linguistica.

Wunderle, Carmen (1998): Sortenmehrdeutigkeit und Argumentstruktur von Ereignisnominalen. Unveröffentlichte Zulassungsarbeit. Universität Tübingen. 